\title{
Urban Religion in Mediterranean Antiquity: Relocating Religious Change
}

\section{Emiliano Rubens Urciuoli and Jörg Rüpke}

\section{Q OpenEdition \\ 1 Journals}

\section{Electronic version}

URL: http://journals.openedition.org/mythos/341

DOI: $10.4000 /$ mythos.341

ISSN: 2037-7746

\section{Publisher}

Salvatore Sciascia Editore

\section{Printed version}

Date of publication: 1 December 2018

Number of pages: 117-135

ISBN: 978-88-8241-501-3

ISSN: $1972-2516$

\section{Electronic reference}

Emiliano Rubens Urciuoli and Jörg Rüpke, «Urban Religion in Mediterranean Antiquity: Relocating Religious Change », Mythos [Online], 12 | 2018, Online since 24 September 2019, connection on 28 September 2019. URL : http://journals.openedition.org/mythos/341 ; DOI : 10.4000/mythos.341 


\section{Urban Religion in Mediterranean Antiquity: Relocating Religious Change}

\section{Emiliano Rubens Urciuoli - Jörg Rüpke}

\section{in collaboration with Asuman Lätzer-Lasar, Harry 0. Maier and Maik Patzelt}

\begin{abstract}
The claim formulated in this article is that city-space and interaction with cityspace engineered the major changes that revolutionised ancient Mediterranean religions. Whereas previous research on ancient religion has stressed the role of religion for cities and urban topography, we are suggesting a new focus on the impact of cities on religion and on how the interaction with city-space changed religion. This side of the dialectic is what we call urban religion. This concept is paramount, since it encompasses the development of specific religious agencies and practices (e.g neighbourhood shrines, theatrical processions; text production and supply of religious services), specific forms of religious knowledge and imaginaries (imaginative places; imagined communities, heavenly cities) and societal phenomena such as civic rituals or religious communities in the appropriation (and hence modification and formation) of urban space in cities of different size and character. The major questions that we propose are: how and to what extent is religion shaped by density, urban aspirations, diversity and conflict, city governance, heterarchical distribution of power and division of labour, and urban identity, that is urbanity? The basic assumption is that religious change needs to be investigated in terms of the ongoing interaction between the city-space and a variety of different agents, including residents, immigrants, and people who live off religion.
\end{abstract}

\section{Riassunto}

La tesi formulata in questo articolo è che lo spazio cittadino e l'interazione con esso innescarono i più grandi mutamenti che rivoluzionarono le religioni mediterranee nell'antichità. Mentre le ricerche precedenti hanno sottolineato il ruolo della religione per la città e per la topografia urbana, la nostra prospettiva suggerisce di concentrare l'attenzione sull'impatto delle città stesse sulla religione, indagando come l'interazione con lo spazio cittadino abbia modificato la religione. Ė questa la prospettiva che definiamo religione urbana. Questo concetto è di importanza fondamentale nella misura in cui include l'emergere di specifiche strutture, agency e pratiche religiose (per esempio, i santuari di quartiere, le processioni teatrali, la produzione di testi e l'offerta di servizi religiosi), specifiche forme di sapere e immaginazione religiosi (luoghi immaginari, comunità immaginarie, città celesti) e fenomeni sociali come rituali civici o comunità religiose esaminate nel loro processo di appropriazione (e quindi di trasformazione) dello spazio urbano in città di differenti dimensioni e tipologia. Le questioni principali che poniamo sono le seguenti: come e in che misura la religione è plasmata dalla densità e dalle aspirazioni urbane, dalla diversità e dal conflitto, dall'amministrazione cittadina, dall'organizzazione 'eterarchica' del potere, dalla divisione del lavoro e dallo stile di vita urbano? L'assunto di base è che il cambiamento religioso necessita di essere indagato in termini di reciproche relazioni tra lo spazio urbano e una varietà di attori sociali, inclusi i residenti, gli immigrati e coloro che vivono della religione.

\section{Keywords}

City - Urban religion - Ancient Mediterranean - religious change

Parole chiave

Città • religione urbana - Mediterraneo antico • cambiamento religioso

\section{Introduction}

o date, religion has been seen as cause for dramatic developments in the history of cities:
foundations, waves of immigration, transformations, ghettoisation, and destruction; it
has been a decisive factor in forming the concept of citizenship as well as in justifying 
the expulsion of large groups, and has contributed to the monumentalisation of centres and or has given importance to ex-centric places. Very recently, sociologists and anthropologists have been discovering religion in the contemporary and supposedly 'secular' global city. ${ }^{1}$ But still awaiting historical investigation is the specific urban character of religious ideas, practices, and institutions and the role of urban space shaping this very 'religion'. As the time-span from the Hellenistic age to Late Antiquity has proven to be crucial in the establishment of concepts and institutions of 'religion', on the one hand, ${ }^{2}$ and is a period of re-newed and more extended waves of urbanization, on the other, ${ }^{3}$ the Mediterranean basin and the Roman Empire offer a rich and comparatively well-documented space for pursuing such an investigation. Taking seriously the proposition that space is condition, medium, and outcome of social relations, ${ }^{4}$ the development of 'religion' in lived urban space as 'urban religion' acknowledges processes of religious change that have been neglected by both the history of religion and the study of ancient urbanism. Our key thesis is that city-space engineered the major changes that revolutionised Mediterranean religions, where this space is understood as the array of urban spatial and structural forms, forces, processes, and agents. Evidently, such a claim is beyond proof in the form of an article. Thus we limit ourselves to plausibilizing this claim as a basis for future investigation against the background of actual research and to developing the conceptual tools for such an enterprise. Thus, we can only indicate lines of research, some of which we will pursue in the near future within the larger comparative framework of a newly established Centre of Advanced Studies in the Humanities on 'Religion and Urbanity', based at the Max-Weber-Kolleg of the University of Erfurt. ${ }^{5}$

\section{Writing City and Religion Spatially in the Ancient Mediterranean}

The history of ancient Mediterranean religion is undergoing a major re-evaluation. All in all, the range of sources regarded as important for reconstructing ancient religion and the developments leading to the formation of those 'late ancient religions' that still are major factors in today's world, such as Judaism, Christianity, and Islam, ${ }^{6}$ all in their many varieties, has been enormously enlarged. For understanding the complexity of religious interaction, the concept of 'lived religion" as developed for contemporary religion has been adapted and enlarged by the ERC-Advanced Grant project 'Lived Ancient Religion' for the study of premodern and specifically ancient Mediterranean religious practices and ideas. ${ }^{8}$ It has showed that funerary ritual and domestic religion, the social and ritual practices of voluntary associations, and the unanticipated, non-civic political use of religion by administrators and political elites

1 Sthran 2015, 35-42; LANZ 2014.

2 RÜPKE 2016.

3 Zuiderhoek 2017, 20-36.

4 Lefebvre 1991 (1974), 2003 (1970), 15; Soja 1989.

5 The project is directed by Susanne Rau and Jörg Rüpke and funded as FOR 2779 by the German Science Founı dation.

6 See Bowersock 1990; Markus 1990; Schwartz 2010. A new journal, edited at the Max Weber Centre, is programmatically encompassing both sides of the assumed antithesis between mono- and polytheism ("Religion in the Roman Empire”).

7 McDannell 1995; Orsi 1999, 2005; McGuire 2008.

8 RÜPKe 2011c, 2016; Albrecht et al. 2018. 
are neither independent strands of religious practice nor replications of, or counter-models to, 'civic religion'. Religion is best conceptualised as a single field of action and forces with many loci of religious authority in permanent fluctuation.

The relationships of religion and space, in general, and between religion and urban space, in particular, are still under-theorized and under-researched. Although practices and discourses previously framed in terms of 'polis religion' have been successfully integrated into the description of 'lived ancient religion', ' the city itself as a living habitat crucial to the religious practices of antiquity and as the driving force of religious change has never been a major concern of research. In almost all research on cities in the deep past (i.e., prior to the late medieval and early modern period), it is mainly assumed that the task is to illustrate how the viability of the city is grounded in a religious identity that is by the same token also a political one. ${ }^{10}$ As scholars' focus has been on political and civic identities, in the history of ancient religion space has been addressed rather reluctantly and above all as imaginary realm. Only very recently has attention been paid to the Roman Empire as a conceptual space of identities and a lived space that informed actual behaviour. ${ }^{11}$ Yet the dominant models remain synchronic and functional with regard to religion or diachronic and hermeneutic in relation to urban space.

It is our contention that the empirical settings of ancient cities are to be viewed and studied specifically as city-spaces, ${ }^{12}$ that is, not only as a built environment as a physical condition, but as a space apprehended as challenging and inspiring, enabling and constraining, featured by particular configurations of social relations, built forms, and human activities which distinguish it from other spatial formations. A paradigmatic site for examining processes of social change at the time of the founding fathers of sociology and urban studies (Weber, Simmel, and the Chicago School), the early $21^{\text {st }}$-century re-emergence of the city as a distinct scientific object of social research ${ }^{13}$ has largely benefited from critical spatial theory (aka spatial turn) and its emphasis on the 'spatial specificity of urbanism'. ${ }^{14}$ Different disciplinary insights now concur in saying the cities are peculiar spatial constellations. Since Michel de Certeau's seminal 'Walking in the City', ${ }^{15}$ urban sociologists, who rarely take anything into account prior to the modern period, have emphasised 'lived' urban space as a praxeological and thus ultimately dialectical relation between the urban space and the human agent, who perceives and appropriates urban space on an individual basis. Scholars of urban planning, social ecology, geography and (political) sociology preferably define cities as phenomena of density with regard to the concentration of people and buildings at certain spots in broader landscapes and to the social consequences of an extreme increase of contact zones. ${ }^{16}$

Drawing critically upon these theoretical insights, our project surveys ancient city-spaces by concentrating on both real and imagined loci of religious experiences and agency. Imagination

9 E.g. Degelmann 2018; Patzelt 2018; Rüpke 2018.

10 See the studies in Yofree 2015a - except Sinopoli focusing on religion in cities dominated by competing merchants.

11 Orlin 2010; Woolf 2011; Mattingly 2011; Eshleman 2012; Ando 2013; Bricault, Bonnet 2013; Collar 2014; RÜPKE 2014; ANDo 2015; MoRgan 2015.

12 Soja 2000, 8; 2006.

13 Sassen 2010; Berking, Löw 2005.

14 Soja 2000, 7-10. On this link see Berking 2008, 15.

15 de Certeau 1984 (1980). $91 \mathrm{ff}$.

16 Löw 2011, 19-21. Also Roskamm 2011; Berking 2008; Nassehi 2002. 
beyond concrete, measurable space, of course, is no privilege of the subalterns and agency is no prerogative of the dominants: against the counter-cultural and utopian accent of the typical use of 'Thirdspace' and 'Heterotopy', we prefer the less normatively charged notion of 'lived space', ${ }^{17}$ without denying that the very nature of religious practices implies the imaginative construction of alternative space beyond any given physical location.

\section{From Civic Religion to Urban Religion}

The very recent rise of the study of religion in contemporary cities focuses on the development of new forms of religious practices, i.e. religious change, and the appropriation of urban space by non-elites. ${ }^{18}$ Our research combines these insights with recent developments in the study of ancient lived religion that acknowledge the plurality of religious agencies and the complexity of religious interaction and appropriations. It aims to demonstrate that many religious phenomena, and especially major religious changes, can be better understood by viewing them in spatial terms, that is, as a result of a spatially informed dialectic of 'coproduction $^{\prime 19}$ of urban life and religious communication in the ancient Mediterranean world from the Hellenistic period to the late imperial period. Focusing on the impact of cities on religion and how the interaction with city-space changed religion, we call this side of the dialectic 'urban religion'.

If our central hypothesis can be sustained, then many features of ancient religion would be more plausibly viewed as the outcome of specific effects and uses of space and their social and cognitive bases rather than as inherent characteristics of a specific 'religion'. Such features are, for instance, the development of certain mass-rituals connected to theatre and circus structures, the widespread staging of theatrical processions, the declining role of animal sacrifice, the 'intellectualisation' of religion and the establishment of specifically religious networks and (initially small) group religions, but also forms of fixating gods to specific places and the very structure of a polytheism informed by a plurality of local temples. By addressing a sufficiently broad range of religious practices, imaginaries, groupings, and professions hitherto examined separately and/or addressed without an eye to urbanism, such a research will elucidate changes in ancient religion as important as the late ancient development of 'religions' (e.g. Christianity, Judaism) as the result of an ongoing interaction of different agents with specifically urban space.

Connected to this historiographical achievement is our ambition to develop and sharpen heuristic concepts and analytical tools that (a) may function as comparative instruments for further research into ancient religion in its many regional varieties, trans-local trajectories, and long-term trends and transformation, and b) help connect past changes with present developments by deepening understanding of both.

Planetary urbanisation is one of the key developments of the present world that cause immense changes in people's daily lives as well as to the landscape of global networks. Praised

17 See Soja 1996, Foucault 1986 (1967), and Lefebvre 1991 (1974), respectively.

18 See Knott 2005; van der Veer 2015; Knott, Krech, Meyer 2016. More literature will be provided below.

19 DAY 2017, 3. 
as the solution to, or cursed at the embodiment of, the major problems of humankind, the 'urban question' is one of the grand challenges of today. Research on Mediterranean Antiquity cannot escape but rather contribute to this discussion by setting ancient religion into a wider framework and by showing that developments in antiquity are relevant even for contemporary concerns. By changing the approach, the outcome of such an agenda will affect claims about the evolutionary role of religion, which is too often viewed in terms of key provider of social cohesion $^{20}$ or examined in ways largely neglectful of individual agency. ${ }^{21}$ Instead of focusing on political integration and social stratification as functional foci of a 'polis'/ civic religion', ${ }^{22}$ we aim to stress urban aspirations, the appropriation of urban space, and the creation of urban diversity. Aside of hierarchy, we attempt to emphasize 'heterarchy'. ${ }^{23}$ Instead of urban trapping and central administration, we highlight network activities. As research on 'Lived ancient religion' has demonstrated, such results are highly relevant to contemporary societal challenges.

The critical use and the establishment of the concept of 'urban religion' are paramount for this task. Defining a 'continual process in which the urban and the religious reciprocally interact, mutually interlace, producing, defining, and transforming each other', ${ }^{24}$ urban religion is the flagship notion of an cross-disciplinary approach to the study of religion in contemporary and preferably global cities that has eventually proven the role of religion in shaping allegedly secularized urban city-spaces and vice versa. Moreover, by significantly enlarging the range of the agents and the motivations involved in the creative co-constitution of religion and urbanity, this body of researches has increasingly made aware of the thoroughness of this interaction. ${ }^{25}$

As demonstrated by the previous research project on 'lived ancient religion', religion is always 'religion in the making' ${ }^{26}$ and thus 'urban religion', too, is a dynamic concept focusing on change. It is inclusive and, when tested on antiquity, it permits analysis of the development of specific religious agency and practices (neighbourhood shrines, theatrical processions; text production and supply of religious services), specific forms of religious knowledge and imaginaries (imaginative places, imagined communities, heavenly cities) and societal phenomena such as civic ritual or religious communities in the appropriation, modification, and formation of urban space. Religious change is always investigated in the ongoing interaction between space and different agents: temporary inhabitants and voluntary or involuntary immigrants, residents and administrators, people living off religion or employing religion for realising their urban hopes.

Yet, in its dominant use on contemporary capitalist urbanism, the object of urban religion is not religion but globalization - with religion rather serving as a lens onto globalization.

20 See most recently NorenZAYAN 2013.

21 See most recently Yoffee 2015b.

22 E.g. Sourvinou-Inwood, C. 1990; Cole 1995; HägG 1996; Sartre 2006; Kindt 2009; Bruun 2009; Evans 2010; Horster 2012; SCHEID 2016.

23 Crumley 1995.

24 LANZ 2014, 26. For a similar definition, see Orsi 1999, 43. For a contextualization, see Garbin, Strhan 2017, 6-11

25 See Orsi 1999; AlSayyas, Massoumi 2011; Garbin 2012 and 2013; Becci, Burchardt, Casanova 2013; Strahn 2015; van de Veer 2015; Goh, van der Veer 2016; Garbin, Sthran 2017; Berking, Steets, SCHWENK 2018; etc.

26 AlbRecht et al. 2018. 
Therefore, the enquired interlacing of globalization, cities, and religion has hardly opened up a real space for historical research, even though historians of religion have been willing to employ this concept for pre-modern phenomena of translocality, universalization, regionalization, localisation and their interactions. ${ }^{27}$ By critically applying the notion of urban religion to ancient Mediterranean cities and religions, our ambition is precisely to thoroughly historicize the analysis of the range of phenomena illuminated by this conceptual tool. For instance, delving into a typical subject matter of the urban-religious research such as 'migrant faiths' and 'diasporic identities', ${ }^{28}$ we aim at understanding the role of religion for migrants and immigrants into cities ${ }^{29}$ by asking whether participation in specific religious activities or networks was a means of stabilising former identities within a new urban space, or rather a strategy for pursuing urban aspirations and developing new identities. This is only possible by strengthening the diachronic scope and reach of urban religion.

\section{Risks and Gains of an Urban Religion Approach}

Evidently, there are some challenges to the viability of the project: a) the distinction between the urban and the non-urban; b) the potential diversity of local trajectories; and c) the sheer scale of such research's scope.

a) Human Geography in general and studies in ancient urbanism in particular ${ }^{30}$ have demonstrated that there is no easy dividing-line between 'city' and 'the rural' - the latter can even be seen as a response to the need for an antithesis to the urban as a result of urbanisation processes. Many religious practices have been conclusively shown to antedate urbanisation, from the basic forms of communicating with divine others in dance, voice, images or gifts to complex rituals like animal sacrifice and moving in groups (processions). Our approach addresses this problem by a basic research strategy that does not attempt to develop criteria for infallibly distinguishing between urban versus non-urban practices but asks whether changes over time in a set of religious phenomena well attested in cities can fruitfully be interpreted as consequences of their contextualisation in and interaction with city-space (what we propose to call 'citification' rather than 'urbanization' of religion). Moreover, instead of drawing an unfoundedly clear-cut religious border, we are interested in monitoring and interpreting the ongoing traffic of religious signs, carriers, practices, and institutions across a more or less externally demarcated and discernible city border, thus testing their endurance and changes under different environmental conditions. Inspired by Jane Jacobs' unrivalled urban imagination, we are looking for cases where rural forms of religion can be explained 'as urban [religion] transplanted'. ${ }^{31}$

Additionally, some well documented rural areas like the 'dead villages' in Syria, rural

27 CANCIK, RüPKe 2009; Rüpke 2011a, 2011b, 2014. On translocality see Freitag, Von Oppen 2010.

28 Garbin 2012, 2013.

29 Holleran 2011; Woolf 2015; Tacoma 2016; Tacoma, Lo Cascio 2017; Lo Cascio 2017.

30 On the contemporary explosion of urban/rural divide the literature is legion, but see, e.g., Soja, KanAI 2006. On antiquity see Wallace-Hadrill 1991; North 1995, 144-145, and several other references in Robinson 2017, 65-70.

31 See Jacobs 1969, 18. 
Britain $^{32}$ or the region of the Ubii $^{33}$ will be used as control cases. Lastly, since the formation of Christianity has been long central to debates about the supposedly 'rural' or 'urban' character of a religious tradition, these still most recent discussions ${ }^{34}$ offer an important touchstone to sharpen our methodology.

b) A second major risk is the potential diversity of local trajectories. Metropoleis such as Rome, Alexandria and Antioch on the Orontes cannot be ignored due to the wealth of material and textual sources they offer, but they are as exceptional as Baghdad, Cairo or Kaifeng in later periods. Were the crucial religious changes that are often associated with these centres, when seen through the lens of spatiality, singular local events? Were they rather connected to the metropolitan size of the city-spaces? Or were they building on more widespread patterns of 'urban religion' as defined above? ${ }^{35}$ Moreover, drawing on Bourdieu's pivotal categories of practical sense (habitus, doxa), ${ }^{36}$ recent sociological research has developed the concept of 'intrinsic logic of cities' ${ }^{37}$ to explain why reaction modes and times to analogous societal challenges and impulses can differ considerably from city to city, even under identical conditions in terms of financial possibilities and institutional frameworks. The possibility to transfer such contemporary explanatory repertoire to ancient city-spaces, and thus eventually to look for 'elective affinities' between certain religious innovations and some specific cities - was a successful religious implementation and religious-branding also the result of a good entrepreneurial sense of the right urban atmosphere? - is fairly limited by the general quality and the uneven quantity of the documentation at hand.

In order to circumvent or limit this risk, our intention is to bring together local case studies selected for historical analyses of a broad range of religious practices, imaginaries, institutions, which pay close attention to the push and pull effects of urban contexts, spatial as well as social and cultural. Granted that many ancient cities have been only partially excavated and even these results only partially published, ${ }^{38}$ we consider that sufficient reliable information has been accumulated to render the project feasible. Research needs to investigate religious change in cross-regional comparisons of cities of different size and character. For instance, in accordance with the concept of 'lived city-space', a line of investigation should focus on the agency of very different types of urban space, namely, on the one hand, dense living quarters, ${ }^{39}$ and, on the other, venues that were built in order to accommodate and communicate with large crowds within a framework of religious rituals, namely circuses, theatres and amphitheatres. This is to be combined with analyses of how human agents adopted antagonistic strategies of appropriating urban space for purposes of attracting (and keeping) religious clients or followers, namely by firmly localising religious practices or developing movable forms of

32 AlLen et al. 2016.

33 Spickermann 2008.

34 See Robinson 2017 against the so-called 'Urban Thesis' (especially, 14-23).

35 These questions can be mapped onto a more general ambiguity of 'urbanity'/'urbanism': see Wüst 64-67. Metropoleis, historically often identical with capitals of empires, tend to display certain trends more clearly but need to be analysed within the broader urban patterns, at work in smaller cities also.

36 See, e.g., Lee 1997; Lindner 2003 ( habitus); Berking 2008 (doxa).

37 See BERKING, Löw 2008; Löw 2012.

38 See critically Raja, Lichtenberger 2015.

39 This was the topic of one of the preparatory conferences of the research project entitled 'Religion of Quarters: Practicing Religion on a Neighbourhood Scale in the Hellenistic and Imperial Periods' (4th-6th July 2018, Haus Hainstein, Eisenach, Germany). The conference proceedings are forthcoming. 
religious practices and imaginaries adaptable to a multifarious urban space. In addition, the interplay between ancient imagination of cities ('cityscaping') ${ }^{40}$ and spatial conceptualisation of religion as a trans-local literary discourse needs to be investigated. A number of cities in the Western and Eastern parts of the Roman Empire offer sufficiently well published material (topographical data, architecture, coins, images), epigraphic, and occasionally even literary evidence to allow for comparison with regard to specific questions.

c) If the geographical extent of exchange relevant for religious signs, practices, ideas and even people, and likewise the impact of urbanisation triggered by the Mediterranean centres, militate against any narrow territorial limitation, the chronological range likewise matters. On the one hand, the bold claims of our research project require that we transcend narrow periods and periodisations. On the other hand, urbanisation (and religion) in the Mediterranean basin and the 'hilly flanks' dates as back as the late, if not the mid-Neolithic period; the empires of the Ancient Near East gave religion a central role in their cities; monumentalised temples and religious festivals (and other religious phenomena) figure prominently in the archaic and classical Greek and Italic poleis. We cannot endeavour to cover this entire range of potential topics in the detail that would be required. In effect, we decided to limit ourselves to the time-span from the Hellenistic age to Late Antiquity, which has proved to be crucial in the establishment of more developed concepts and more institutionalised forms of 'religion'. At the same time this is a period of renewed and more extended waves of urbanisation. ${ }^{41}$ The residual risk of overstretch will be reduced by addressing only phenomena essential from the point of view of spatial theory as well as history of religion as outlined above and substantiated below. The focus is on religious rather than urbanistic change.

High risks are associated with high gains. The range of the topic and the breadth of the approach will lead to new narratives of this period of history of religion and will impact on the study of religion and urbanism more generally. A new explanation for the appearance of 'religions' in this period may be found in the proposition that it was the continuing close proximity to anonymous strangers and religious others that created a need to intensify group boundaries, magnify small differences, foster rhetoric to delegitimize the beliefs and practices of others, and encourage religious entrepreneurship. Religious change could be pinpointed more precisely in the social and cultural fabric by focusing on topics and processes such as theatrical rituals, intellectualisation, historicization, canonisation and scriptural interpretation, religious legislation (ecclesiastical and Rabbinic), and images of ideal or heavenly cities (Platonopolis, Jerusalem or civitas dei). In short, if successful, the large-scale analysis undertaken will fundamentally change our understanding of major changes in that period of Mediterranean religion not only with regard to 'ancient religion' but also to the formative periods of Judaism and Christianity. Moreover, the establishment of 'urban religion' as a new paradigm of analysis and description should have an impact on the historical study of religion and the study of religion in cities more generally. Far beyond the discourse on ancient religion, the topics of urbanisation, migration and mobility, and diversity, which are the major issues covered by our research plan, will enable Classical Studies to relate to most relevant contemporary debates in the field of Humanities and Social Sciences, thereby helping to critically connect contemporary observations to long-term historical change observable in what is now known as the 'laboratory' of the past.

40 Fuhrer, Mundt, Stenger 2015; also partly Kemezis 2015.

41 Including incipient phenomena of de-urbanisation in Late Antiquity. See Rizos 2017. 


\section{Definitional issues and key analytical tools}

How can we make plausible the bold claim that city-space and interacting with city-space engineered the major changes that revolutionised Mediterranean religions? How can we determine how and to what extent religious practices, imaginaries and institutions changed or developed in lived urban space? And how far can we speak of a co-constitution of practices of religious communication and urban spatiality? Responses to all these questions call for the use of well considered concepts defining our object of research, starting with 'city' and 'religion', as well as for the selection of key analytical tools to navigate the amount of potential evidence and research tracks.

\section{City}

For the purposes of the project and against the background of the state-of-the-art, ${ }^{42}$ we prefer to avoid clear-cut and highly technical definitions of city valid only for specific cultures. Very large conceptualizations are no heuristically serviceable either. Nor is our intention to draw on existing typologies or construct new ideal types to be added to an already thriving taxonomic panorama. Rather, we opt for a polythetic approach that deliberately selects out characteristics which are of prime importance for our research questions and thus understands cities as places with the following features :

- City is a spatial form that organises and regulates phenomena of density on a larger scale (bigh density)

- City is a place offering specific opportunities and evoking distinctive hopes (urban aspirations)

- City is a place engendering diversity and endemic conflict (diversity)

- City is a place subject to administrative attempts at comprehensive organisation (governmental power)

- At the same time, city is a place functioning as a heterarchical system, where power can be ranked in a number of ways, shared, or checked (heterarchy)

- City is a place inhabited by a substantial population of non-food-producing individuals pursuing different trades (including intellectual occupations) on the basis of an agricultural surplus (division of labour)

- City is a place that is recognised as city and defined contrastively against (culturally variable forms of) non-city (urbanity)

\section{Religion}

For the purposes of the project, we theorise religion as communication with special agents (sometimes including objects) with properties different from everyday human, that is, dead

42 Already in 1950, the Australian Marxist archaeologist Vere Gordon Childe opened one of the most heavily cited pieces in the history of archaeology ('The Urban Revolution') by saying that 'the concept of city is notoriously hard to define' (Childe 1950, 3). Over time, this statement has become proverbial among specialists of different disciplines, as well as particularly convenient to advertise 'a somewhat fuzzy core concept rather than to try to establish criteria that will clearly demarcate all cities from all noncites' (Cowgill 2004). It is still true, however, that 'neither anthropologists nor geographers have been able to agree on a generally acceptable cross-cultural [and cross-temporal] definition of urbanism' (Trigger 1972, 576). Non-definitional approach to the issue relying on human capacities on mental mapping are also possible: thus FinLey 1977, 305. For an overview of five conceptually different approach to the classification of urban forms, see TRIGGER 1972; most recently SMITH et al. 2016. 
(ancestors) or unborn (angels), just (demon) or fully superhuman (gods) agents to whom agency is accorded in a not unquestionably plausible way. Communication with or concerning such divine agents might reinforce or reduce human agency, create or modify social relationships, and change power relationships. ${ }^{43}$ This is of particular interest with regard to the frequent encounters and dense networks but also fluid and exchangeable relationships ('weak ties') typical of cities. Furthermore, like any other cultural practice, religious communication is a spatio-temporal practice induced and shaped by the spatial organization and, in turn, recreating space. ${ }^{44}$ At the same time, our conceptualization of religion suggests that there is a specific spatial character of religious communication, a conceptual relationship not likewise valid for other cultural practices. If place-making can be equated with 'dwelling' and is frequently achieved with religious practices, religious communication is inherently also a practice of 'crossing. ${ }^{45}$ 'Religion' as used here is defined as an action transcending (in a very simple sense) the immediate and unquestionably given situation, that is, temporarily and situationally enlarging the environment judged as relevant by one or several actors. ${ }^{46}$ In the ancient Mediterranean world, just as today, the spatial character of religious communication was reinforced by sacralising objects or places and was thus manifest in material form even in other uses of space. ${ }^{47}$ Creating religious space was part of an ongoing process of claiming and appropriating urban space which implies specific competitive dynamics of place making involving both physical and rhetorical strategies. ${ }^{48}$

\section{Key concepts}

The manifold ways in which religion is used by different agents to deal with city-spaces, as well as the extent to which urban spatiality affects forms of religious practices, are elucidated with the help of three key concepts, which are deployed and interlaced throughout the project: a) agency and aspiration, b) spatial imagination, and c) appropriation.

a) Agency and aspiration. Agency can be afforded to objects. By their form or very presence they make humans re-act, 'afford' certain behaviour. ${ }^{49}$ We use the concept of 'agency of objects' and places but likewise focus on human agency and creativity within social contexts and situations. We conceive agency as the constant interaction between people that creates the structures and traditions that constrain and limit the subsequent exercise of agency, which in turn may alter or even challenge those same structures and traditions. ${ }^{50}$ As outlined above, religion enlarges the field of agency. By invoking in specific situations agents or authorities held to be divine, religious agents acquire extended possibilities for imagining and acting. Yet the converse is also possible: the same mechanism can also trigger an abjuration of personal agency, resulting in impotence and passivity, with agency being reserved for the divine agents.

43 RÜPKE 2015.

44 Клотт 2005.

45 For this tension, see TweEd 2006.

46 In this sense, the trans-local references inherent to religious communication by way of agency claims need not wait for radicalised axial-age transcendence and posterior debates on icons, re-presentation and presence, anthropomorphic or non-anthropomorphic forms, images or no image, etc. (cf. Bellah 2011; Bellah, Joas 2012).

47 Insoll 2009; Droogan 2013; Raja, Rüpke 2015.

48 On this see most recently LANDER 2017.

49 Gosden 2005, Hodder 2012.

50 Joas 1996, Emirbayer, Mische 1998. 
A specific aspect of agency related to city-space is captured by a further term. Recent urban studies have taken up the term 'aspirations' from studies of social mobility ${ }^{51}$ to designate specific driving motifs and attitudes of immigrants as well as homegrown inhabitants: namely, 'forward-looking hopes of achievement' instantiated in ideas and behaviours connected with urban life and mobilized in ways that 'engage and overcome' urban issues. The situations in which religiously infused motivations stir urban creativity or create alternative urban worlds, or urban concerns are conducive to religious innovations, are described by the dialectical notion of 'urban religious aspirations'. ${ }^{52}$ One of the aims of this project is to build on and develop this rather vague concept on the basis of historical research, at the same time exploring the possibility of a mutually exclusive relationship between religious and urban concerns. The socially uneven, though universal, cross-cultural, and -temporal capacity to engage agentically with the urban environment and to aspire in relation with it is to be used to nuance the analysis and description of individual and collective agents in structured situations.

b) Spatial imagination. Lefebvre's notion of 'lived' space has taught us that agents do not merely 'perceive' or 'conceive' urban space. ${ }^{53}$ Whereas perceived space describes spatial practices that reproduce a spatial order (in the case of the urban, by mapping daily routines onto the established blueprints of everyday urban reality), and conceived space refers to the intellectually worked out dominant conceptions of space (e.g., that of the urban planners, social engineers, and administrative authorities), lived space highlights the human aspirational capacity to imagine space differently, to overlay it with unanticipated systems of symbols and signs, in a word: to change its use and appropriate it. ${ }^{54}$ Accordingly, urban-based human agents develop alternative 'representational spaces', new ways of using the city-space and, moreover, new forms of memorising, symbolising, imagining, and transcending urban spaces beyond their commonsensically perceived and professionally designed spatial layouts - including fictional spaces, theoretical spaces, or dreamed/utopian spaces as modelled by philosophers, poets and religious specialists. The city, thus, reveals itself as 'an imaginative object', an everchanging assemblage of views that in turn conditions particular spatial practices. ${ }^{55}$ Already highlighted by Lefebvre, ${ }^{56}$ the role played by religion in producing lived space is foregrounded by considering religious imagination and practice as spatial imagination and practice that do not just reproduce or legitimize existing knowledge already attached to a location but actually creates new interpretations, meanings, and uses by drawing upon extraneous religious knowledge. At the same time, the users' practice and the knowledge of the city produces and affects lived religion. Hence the concept of spatial imagination helps to elucidate key dynamics of the dialectic between urban space and religious practice and knowledge in our evidence.

c) Appropriation. Over the last decades, postcolonial and subaltern studies have rehabilitated the hitherto negatively charged notion of appropriation (i.e., to make one's own) by explaining it as 'a potentially two-way process' where 'exchange and creative response may take place'. ${ }^{57}$ In its far less controversial sociological use, which we mainly refer to, the term describes a specific

51 Appadurai 2004.

52 VAN der Veer 2015; GoH, van der Veer 2016.

53 See already LYNCH 196.

54 Lefebvre 1991, 38-39.

55 Blum 2003, 13-20.

56 LefebVre 1991, passim.

57 Ashley, Plesch 2002, 6. 
transformation process of the relations between human agents and human-made products (language, things, space) whereby the former agentically adopt and adapt the latter by gaining power and/or stressing identity via and over them. Appropriation can thus designate the 'innumerable and infinitesimal transformations ${ }^{\prime 58}$ of a language by the speakers, the creative transition of a thing from being an anonymous commodity to a highly personal good, ${ }^{5}$ the tactical interpretation of the city-space by the footsteps of its walkers. In de Certeau's seminal praxeological analyses, the frequent use of the term always implies a focus on the acts and practices of the consumer rather than on the producer, or better: on the proactive and productive character of consumption. ${ }^{60}$ This logic shuffles (and, for its critics, blurs) the hierarchical directionality of cultural processes (designer/public; active/passive; etc.) in a manner that resonates with the nowadays' fashionable business term of 'prosumer'. Successful appropriations emphasise the multidimensionality and polysemous nature of signs, things or spaces, but they are conditional upon the decisions and requirements of the agents themselves in concrete situations, as well as upon their social roles and the related expectations. ${ }^{61}$

Like any other cultural practice, religious communication engages with space, in general, and urban space, in particular, in ways that can be described as 'appropriation'. Preceded by a selection, this use recognises and accepts the character of spaces as defined by previous, common or prescribed usages, but it also modifies the space through performance and thus changes the future memory of the place. Religious traditions themselves, of course, are not simply given, but need permanent reproduction and are transformed by the (also) spatiotemporally contingent modifications of the users (most frequently micro-changes but sometimes revolutionary). Appropriations of city-space and inner-city areas and locales by religious agents can be both ephemeral and long-lasting, rhythmical or permanent. Massive investments in media as tool for the communication with not unquestionably given addressees impinge significantly on the durability of the processes of appropriation.

\section{Conclusion}

As stressed in the beginning, this article does not historically substantiate any far-ranging claims but develops a coherent research programme. Against the background of research on religion in ancient Mediterranean cities, above all for the Hellenistic and Roman period, we argued for a change of perspective: from histories of religion that trace religious practices and ideas as an expression of political change in cities to the assumption that city-space engineered the major changes that revolutionised Mediterranean religions, where this space is understood as the array of urban spatial and structural forms, forces, processes, and agents. Of course, cityspace in itself is not an independent variable, but again a result of complex, cultural, economic, and political interactions with and as space. Yet it is the spatial dimension that is foregrounded. We briefly discussed the possible risks and gains of such an approach in the wider horizon of geographical, urban, and religious studies. The main emphasis of the article, however, was

58 de Certeau 1984 (1980), XIV.

59 CARRIER 1995, 107-126.

60 De Certeau 1984 (1980).

61 CARrIER 1995, 117-120 (on the gendered quality of appropriations). 
on developing conceptual tools that allow for an adequate heuristic and description of the processes that we assume to be of paramount importance. It is on this basis that we intend to pursue and invite further research and criticism.

\section{Emiliano Rubens Urciuoli \& Jörg Rüpke} Universität Erfurt Max-Weber-Kolleg für kultur- und sozialwissenschaftliche Studien

Nordhäuser Str. 63 99089 Erfurt

emiliano.urciuoli@uni-erfurt.de joerg.ruepke@uni-erfurt.de 
Bibliography

Albrecht et AL. 2018

J. Albrecht et al., "Religion in the Making: The Lived Ancient Religion Approach", Religion 48, 4 (2018), 568-593.

Allen et al. 2016

M. Allen et al., The Rural Settlement of Roman Britain: An Online Resource, http:// archaeologydataservice.ac.uk/archives/view/ romangl/ (updated 2016).

AlSayyad, Massoumi 2011

N. AlSayyad, M. Massoumi (eds.), The Fundamentalist City? Religiosity and the Remaking of Urban Space, London 2011.

ANDo 2013

C. Ando, «Subjects, Gods, and Empire, or Monarchism as a Theological Problem", in J. Rüpke (ed.), The Individual in the Religions of the Ancient Mediterranean, Oxford 2013, 85111.

Ando 2015

C. Ando, Roman Social Imaginaries: Language and Thought in Contexts of Empire, Toronto 2015.

Appadurai 2004

A. Appadurai, «The Capacity to Aspire: Culture and the Terms of Recognition", in V. Rao, M. Walton (eds.), Culture and Public Action, Stanford 2004 59-84.

Becci, Burchardt, Casanova 2013

I. Becci, M. Burchardt, J. Casanova, J. (eds.), Topographies of Faith: Religion in Urban Spaces, Leiden 2013.

Ashley, Plesch 2002

K. Ashley, V. Plesch, "The Cultural Processes of 'Appropriation", Journal of Medieval and Early Modern Studies 32, 1 (2002), 1-15.

BeLlah 2011

R.N. Bellah, Religion in Human Evolution: From the Palaeolithic to the Axial Age. Cambridge, Mass (2011).

BeLlah 2008

R.N. Bellah, H. Joas (eds.), The Axial Age and Its Consequences. Cambridge, Mass 2012.

\section{BERKING 2008}

H. Berking, "Städte lassen sich an ihrem Gang erkennen wie Menschen': Skizzen zur Erforschung der Stadt und der Städte», in M. Löw; id. (eds.), Die Eigenlogik der Städte. Frankfurt/M 2008, 15-31.

BERKING, LÖW 2005

H. Berking, M. Löw, «Wenn New York nicht Wanne-Eickel ist ... Über Städte als Wissensobjekt der Soziologie», in idd. (eds.), Die Wirklichkeit der Städte, Baden-Baden 2005, 9-22.

Berkin, Steets, Schwenk 2018

H. Berking, S. Steets, J. Schwenk, (eds.). 2018. Religious Pluralism and the City Inquiries into Postsecular Urbanism, London 2018.

BLUM 2003

A. Blum, The Imaginative Structure of the City, Montréal 2003.

BOWERSOCK 1990

G.W. Bowersock, Hellenism in Late Antiquity, Cambridge 1990.

Bricault, Bonnet 2013

L. Bricault, C. Bonnet, C. (eds.), Panthée: Religious Transformations in the Graeco-Roman Empire. Leiden 2013.

BRUUN 2009

C. Bruun, "Civic Rituals in Imperial Ostia», in O. Hekster, S. Schmidt-Hofner, C. Witschel (eds.), Ritual dynamics and religious change in the Roman Empire: Proceedings of the Eighth Workshop of the International Network Impact of Empire (Heidelberg, July 5 - 7, 2007), Leiden 2009, 123-141.

CANCIK, RÜpKe 2009

H. Cancik, J. Rüpke, (eds.), Die Religion des Imperium Romanum. Koine und Konfrontationen. Tübingen 2009.

CARrier 1995

J.G. Carrier, Gifts and Commodities: Exchange and Western Capitalism since 1700, London 1995. 
Childe 1950

V.G. Childe, "The Urban Revolution», Town Planning Review 21 (1950), 3-17.

Cole 1995

S.G. Cole, 1995. "Civic Cult and Civic Identity", in M. H. Hansen (ed.), Sources for the Ancient Greek City-State, København (1995), 292-325.

Collar 2014

A. Collar, Religious Networks in the Roman Empire: The Spread of New Ideas. Cambridge 2014.

Cowgill 2004

G.L. Cowgill, "Origins and Development of Urbanism: Archeological Approaches", Annual Review of Anthropology 33 (2004), 525-549.

Crumley 1995

C.L. Crumley, "Heterarchy and the Analysis of Complex Societies", Archaeological Papers of the American Anthropological Association 6 (1995), 1-5.

DAY 2017

K. Day, "Urban Space and Religion in the United States», Oxford Research Encyclopaedia of Religion. 1-16 (2017). DOI: 10.1093/ acrefore/9780199340378.013.470.

de Certau 1984 (1980)

M. de Certeau, The Practice of Everyday Life, Berkeley 1984 (1980).

Degelmann 2017

C. Degelmann, Squalor: Symbolisches Trauern in der politischen Kommunikation der römischen Republik und frühen Kaiserzeit Stuttgart 2017.

Droogan 2013

J. Droogan, Religion, Material Culture and Archaeology, London 2013.

EMirbayer, Mische 1998

M. Emirbayer, A. Mische, "What Is Agency?" American Journal of Sociology 103 (1998), $962-$ 1023.

\section{ESHLEMAN 2012}

K. Eshleman, The Social World of Intellectuals in the Roman Empire: Sophists, Philosophers, and Christians, Cambridge 2012.
Evans 2010

N. Evans, Civic Rites: Democracy and Religion in Ancient Athens, Berkeley 2010.

FinLEY 1977

M.I. Finley, «The Ancient City: From Fustel de Coulanges to Max Weber and Beyond", Comparative Studies in Society and History 19, 3 (1977), 305-327.

Foucault 1986 (1967)

M. Foucault, «Of other spaces», Diacritics 16 (1986 [1967], 22-27.

Freitag, van Oppen 2010

U. Freitag, A. van Oppen (eds.), Translocality: The Study of Globalising Processes from a Southern Perspective, Leiden 2010.

Fuhrer, Mundt, Stenger 2015

T. Fuhrer, F. Mundt, J. Stenger (eds.), Cityscaping: Constructing and Modelling Images of the City, Berlin 2015.

GARBIN 2012

D. Garbin, «Marching for God in the global city: Public space, religion and diasporic identities in a transnational African church", Culture and Religion 13, 4 (2012), 425-447.

Garbin 2013

D. Garbin, «The Visibility and Invisibility of Migrant Faith in the City: Diaspora Religion and the Politics of Emplacement of AfroChristian Churches», Journal of Ethnic and Migration Studies 39, 5 (2013), 677-696.

Garbin, Strahn 2017

D. Garbin, A. Strahn (eds.), «Introduction», in Idd. (eds.). Religion and the Global City. London 2017, 1-24.

GoH, van der Veer 2016

D.P.S. Goh, P. van der Veer, «Introduction: The Sacred and the Urban in Asia", International Sociology 31 (2016), 367-374.

Gosden 2005

C. Gosden, «What Do Objects Want?», Journal of Archaeological Method and Theory 12 (2005), 193-211.

HäGG 1996

R. Hägg (ed.), The Role of Religion in the Early Greek Polis, Stockholm 1996. 
HodDer 2012

I. Hodder, Entangled: An Archaeology of the Relationships between Humans and Things. Chichester 2012.

Holleran 2011

C. Holleran, «Migration and the urban economy of Rome», in Ead., A. Pudsey (eds.). Demography and the Graeco-Roman World, Cambridge 2011, 155-180.

HORSTER 2012

M. Horster, Civic Priests: Cult Personnel in Athens from the Hellenistic period to Late Antiquity, Berlin 2012.

INSOLL 2009

T. Insoll, «Materiality, Belief, RitualArchaeology and Material Religion: An Introduction», Material Religion 5 (2009), 260-264.

JACOBS 1969

J. Jacobs, The Economy of Cities, New York 1969.

JOAS 1996

H. Joas, Die Kreativität des Handelns, Frankfurt a. M 1996.

Kemezis 2014

A.M. Kemezis, Urban Dreams and Realities in Antiquity. Remains and Representations of the Ancient City, Leiden 2014.

KINDT 2009

J. Kindt, Polis Religion - A Critical Appreciation. Kernos 22 (2009), 9-34.

KNOTT 2005

K. Knott, The Location of Religion: A Spatial Analysis, London 2005.

Knott, Krech, Meyer 2016

K. Knott, V. Krech, B. Meyer, «Iconic Religion in Urban Space», Material Religion 12 (2016), 123-136.

LANDER 2017

S.L. Lander, Ritual Sites and Religious Rivalries in Late Roman North Africa, Cambridge 2017.

LANZ 2014

S. Lanz, "Assembling Global Prayers in the City: An Attempt to Repopulate Urban Theory with Religion», in J. Becker et al. (eds.), Global Prayers: Contemporary Manifestations of the Religious in the City, Zürich 2014, 16-47.

LeE 1997

M. Lee, «Relocating Location: Cultural Geography, the Specificity of Place and the City Habitus», in J. McGuigan (ed.). Cultural Methodologies, London 1997, 126-141.

LeFEBVRE 1991

H. Lefebvre, The Production of Space, Oxford 1991 (1974).

LeFEBVRe 2003

H. Lefebvre, The Urban Revolution. Minneapolis 2003 (1970).

LIDNER 2003

R. Lindner, «Der Habitus der Stadt: Ein kulturgeographischer Versuch", Petermanns Geographische Mitteilungen 147 (2003), 46-53.

Lo Cascio 2017

E. Lo Cascio, «Migration et droit dans l'Empire Romain: Catégories, contrôles et intégration», in E. Lo Cascio, L. E. Tacoma, M. J. GroenVallinga (eds.), The impact of migration on the demographic profile of the city of Rome: $A$ reassessment, Leiden 2017, 23-32.

Löw 2011

M. Löw, «'Jede Stadt hat einen Seelenzustand': Über städtische Vergesellschaftung und Identitätsanforderung», in A. Hoppe (ed.), Raum und Zeit der Städte: Städtische Eigenlogik und jüdische Kultur seit der Antike, Frankfurt/M. 2011, 11-24.

Löw 2012

M. Löw, «The Intrinsic Logic of Cities: Towards a New Theory of Urbanism", Urban Research \& Practice 5, 3 (2012), 303-315.

LYNCH 1960

K. Lynch, The Image of the City, Cambridge, Mass 1960.

MARKUS 1990

R.A. Markus, The End of Ancient Christianity, Cambridge 1990.

MatTingly 2011

D.J. Mattingly, Imperialism, Power and Identity: 
Experiencing the Roman Empire, Princeton 2011.

McDannell 1995

C. McDannell, Material Christianity: Religion and Popular Culture in America, New Haven 1995.

McGuire 2008

M. McGuire, Lived Religion: Faith and Practice in Everyday Life, New York 2008.

Morgan 2015

T. Morgan, Roman Faith and Christian Faith: Pistis and Fides in the Early Roman Empire and Early Churches, Oxford 2015.

NASSEHI 2002

A. Nassehi, «Dichte Räume. Städte als Synchronisations- und Inklusionsmaschinen", in M. Löw (ed.), Differenzierung des Städtischen, Opladen 2002, 211-232.

NoRENZAYAN 2013

A. Norenzayan, Big Gods: How Religion Transformed Cooperation and Conflict, Princeton 2013.

\section{North 1995}

J.A. North, "Religion and Rusticity», in T. J. Cornell; K. Lomas, Urban Society in Roman Italy. London 1995, 141-156.

OrLIN 2010

E.M. Orlin, Foreign Cults in Rome: Creating a Roman Empire, Oxford 2010.

ORSI 1999,

R. Orsi (ed.), Gods of the City: Religion and the American Urban Landscape Religion in North America, Bloomington 1999.

ORSI 2005

R. Orsi, Between Heaven and Earth: The Religious Worlds People Make and the Scholars Who Study Them, Princeton 2005.

\section{Patzelt 2018}

M. Patzelt, Über das Beten der Römer: Gebete im spätrepublikanischen und frühkaiserzeitlichen Rom als Ausdruck gelebter Religion, Berlin 2018.

RAja, Lichtenberger 2015

R. Raja, A. Lichtenberger, «New Archaeological Research in the Northwest Quarter of
Jerash and Its Implications for the Urban Development of Roman Gerasa", American Journal of Archaeology 119 (2015), 483-500.

RAJA, RÜPKE 2015

R. Raja, J. Rüpke, «Archaeology of Religion, Material Religion, and the Ancient World", in Idd. (eds.), A Companion to the Archaeology of Religion in the Ancient World, Malden 2015, $1-25$.

Rizos 2017

E. Rizos, New Cities in Late Antiquity: Documents and archaeology, Turnhout 2017.

Robinson 2017

T.A. Robinson, Who Were the First Christians: Dismantling the Urban Thesis, Oxford 2017.

RosKamm 2011

N. Roskamm, Dichte: Eine transdisziplinäre Dekonstruktion. Diskurse zu Stadt und Raum, Bielefeld 2011.

RÜPKE 2011a

J. Rüpke, «Rei,chsreligion? Überlegungen zur Religionsgeschichte des antiken Mittelmeerraums in römischer Zeit", Historische Zeitschrift 292 (2011), 297-322.

RÜPKE 2011b

J. Rüpke, "Roman Religion and the Religion of Empire: Some Reflections on Method", in J.A. North, S.R.F. Price (eds.), The Religious History of the Roman Empire: Pagans, Jews, and Christians, Oxford 2011, 9-36.

RÜPKE 2011c

J. Rüpke, «Lived Ancient Religion: Questioning 'Cults' and 'Polis Religion'», Mythos 5 (2011), 191-204.

RÜPKE 2014

J. Rüpke, From Jupiter to Christ: On the History of Religion in the Roman Imperial Period, Oxford 2014.

RÜPKE 2015

J. Rüpke, «Religious Agency, Identity, and Communication: Reflecting on History and Theory of Religion», Religion 45 (2015), 344366. 
RÜPKE 2016

J. Rüpke, On Roman Religion: Lived Religion and the Individual in Ancient Rome, Ithaca, NY (2016).

RÜPKE 2018

J. Rüpke, Pantheon: A New History of Roman Religion, Princeton 2018.

SARTRE 2006

M. Sartre, "Religion und Herrschaft: Das Seleukidenreich». Saeculum 57, 2 (2006), 163 190.

\section{SASSEN 2010}

S. Sassen, "The city: Its return as a lens for social theory», City, Culture and Society 1 (2010), 3-11.

SCHEID 2016

J. Scheid, The Gods, the State, and the Individual: Reflections on Civic Religion in Rome (Trans C. Ando), Philadelphia 2016.

SCHWARTZ 2010

S. Schwartz, Were the Jews a Mediterranean Society? Reciprocity and Solidarity in Ancient Judaism. Princeton 2010.

Sмiтн 2016

M.E. Smith et al., "Comparative Methods for Premodern Cities: Coding for Governance and Class Mobility", Cross-cultural Research 50, 5 (2016), 415-451.

Soja 1989

E.W. Soja, Postmodern Geographies: The Reassertion of Space in Critical Social Theory, London 1989.

Soja 1996

E.W. Soja, Thirdspace: Journeys to Los Angeles and Other Real-and-Imagines Places, Oxford 1996.

SoJa 2000

E.W. Soja, Postmetropolis: Critical Studies on Cities and Regions, Oxford 2000.

Soja 2006

E.W. Soja, "Foreword: Cityscapes as cityspaces." In: C. Lindner (ed.). Urban Space and Cityscapes: Perspectives from modern and contemporary culture. London. XV-XVIII.
Soja, Kanai 2006

E.W. Soja; J.M. Kanai, «The Urbanization of the world", in R. Burdett, D. Sudjic (eds.), The Endless City. New York 2006, 54-69.

Sourvinou-Inwood 1990

C. Sourvinou-Inwood, "What is Polis Religion?», in O. Murray, S. Price (eds.), The Greek City: From Homer to Alexander, Oxford 1990, 295-322.

SPICKERMANN 2008

W. Spickermann, Religionsgeschichte des römischen Germanien 2: Germania Inferior, Tübingen 2008.

STHRAN 2015

A. Sthran, Aliens and Strangers? The Struggle for Coherence in the Everyday Lives of Evangelicals, Oxford 2015.

TACOMA 2016

L.E. Tacoma, Moving Romans: Migration to Rome in the Principate, Oxford 2016.

Tacoma, Lo Cascio 2017

L.E. Tacoma, E. Lo Cascio, «Writing Migration», in E. Lo Cascio, L. E. Tacoma, M. J. Groen-Vallinga (eds.), The Impact of Mobility and Migration in the Roman Empire: Proceedings of the Twelfth Workshop of the International Network Impact of Empire (Rome, June 17-19, 2015), Leiden 2017, 1-24.

Trigger 1972

B.G. Trigger, «Determinants of urban growth in pre-industrial societies», in P. J. Ucko, R. Tringham, G. W. Dimbleby (eds.), Man, Settlement, and Urbanism, Gloucester Crescent 1972, 575-599.

Tweed 2006

T.A. Tweed, Crossing and Dwelling: A Theory of Religion, Cambridge, Mass 2006.

VAN DER VEER 2015

P. van der Veer, Handbook of Religion and the Asian City: Aspiration and Urbanization in the Twenty-First Century, Oakland 2015.

WALLACE-HaDRILL 1991

A. Wallace-Hadrill, «Introduction», in J. Rich; A. Wallace-Hadrill, City and Country in the Ancient World, London 1991, IX-XVII. 
WoOLF 2011

G. Woolf, Tales of the Barbarians: Ethnography and Empire in the Roman West, Malden 2011.

Woolf 2015

G. Woolf, «Movers and Stayers», in L. de Ligt; L. E. Tacoma (eds.), Migration and Mobility in the Early Roman Empire, Leiden 2015, 438461.

WÜsт 2004

T. Wüst, Urbanität. Ein Mythos und sein Potential, Wiesbaden 2004.
Yoffee 2015a

N. Yoffee, The Cambridge World History 3: Early Cities in Comparative Perspective, 4000 BCE1200 CE, Cambridge 2015.

YofFeE 2015b

N. Yoffee, "Conclusion: The Meaning of Early Cities", in N. Yoffee (ed.), The Cambridge World History 3: Early Cities in Comparative Perspective, 4000 BCE-1200 CE, Cambridge 2015, 546-557.

ZuIDERHOEK 2017

A. Zuiderhoek, The Ancient City, Cambridge 2017. 